\title{
УДК: 630*561.26: 519.876 \\ СИНХРОННАЯ ДИНАМИКА ШИРИНЫ ГОДИЧНЫХ СЛОЕВ У ПОПУЛЯЦИИ ДУБА ЧЕРЕШЧАТОГО (QUERCUS ROBUR L.)
}

\author{
П.М. Мазуркин ${ }^{1}$, Д.В. Тишин ${ }^{2}$ \\ ${ }^{1}$ Поволжский государственный технологический университет, \\ Йошкар-Ола, Республика Марий Эл, 424000, Россия, kaf_po@mail.ru \\ ${ }^{2}$ Институт экологии и географии, Казанский (Приволжский) федеральныий \\ университет, Казань, Республика Татарстан, 420008, Россия, Denis.Tishin@kpfu.ru
}

Аннотация. По методу кернов, взятых возрастным буравом на 10 деревьях дуба черешчатого (Quercus robur L.), приведены статистические модели синхронной ежегодной динамики суммарной ширины годичных слоев на высоте 0,5 м от корневой шейки. Показаны вейвлет-сигналы поведения популяции с 1850 по 2004 гг., даны этапы жизнедеятельности популяции. Приведена методика вейвлет-анализа динамики поведения дубов. Доказано, что жизнедеятельность популяции дубов протекает с волновой адаптацией к внешним воздействиям.

Ключевые слова: дуб, популячия, керны, годичные слои, суммарная ширина, вейвлетанализ, закономерности

\section{ВВЕДЕНИЕ}

В популяционной динамике $[11,12]$ статистическим моделированием $[15,16,27]$ выявляют волновые закономерности динамики радиального роста ствола дерева, а по полученной статистической модели прогнозируют изменение радиуса ствола дерева в перспективу и ретроспективу [10, 28].

Опыт моделирования в дендрохронологии показан в работах $[2,4,11,12,18-22]$. Получены закономерности ширины годичного слоя поэтапного [22] для сосны 250 лет и минимаксного градиентного анализа ряда в 650 лет [16] ставропольской ели на кернах древесины. По данным [6] минимаксным градиентным анализом были получены волновые формулы для ширины годичных слоев можжевельника 808 лет.

Существование годичного кольца как слоистой структуры объясняется законом Пуазейля для жидкости, а также законами, определяющими прочность материала от его геометрических характеристик [30].

Цель статьи - показать новый метод вейвлет-анализа [7-9, 13-15] синхронной динамики ширины годичного слоя у популяции дуба. При этом предполагается, что измерения и датировка годичных слоев до статистического моделирования были выполнены [29].

Идентификация устойчивых закономерностей позволяет преобразовать табличные модели, которых много накопилось и в публикациях по дендрохронологии, например в $[1,6,15]$, в высокоадекватные волновые уравнения с переменными амплитудами и периодами колебательного возмущения.

Каждое волновое уравнение является ассиметричным вейвлет-сигналом [7-9, 13 15] из прошлой жизнедеятельности испытуемого дерева. Из современных космологических теорий известны так называемые «уединенные волны» (солитоны), которые, как показали наши исследования, влияют на ритмику поведения растущих деревьев. При этом наибольшее влияние на динамику развития и роста растений оказывают циклы солнечной активности по известному физическому эффекту А.Л. Чижевского [10].

Сразу же отметим, что волны в поведении деревьев оказываются переменными по частоте и амплитуде. По-видимому, процессы развития и роста произрастающего дерева уже в семени и росточке синхронизированы с мировыми волнами [26], а затем эти стартовые значения амплитудно-частотных характеристик дерева меняются с 
возрастом, прежде всего, из-за колебательной адаптации организма к среде своего обитания [25] и даже к резко изменяющимся природным и природно-антропогенным импульсным воздействиям, например, в виде рубки деревьев [23].

Комплексы волновых уравнений, в совокупности моделирующие процессы поведения древесного растения до погрешности проведенных измерений, позволяют расшифровать «жгут волн» прошлых взаимодействий древесного организма с окружающей его средой. В данной статье приводятся результаты идентификации динамики только ширины годичных слоев на кернах [29].

На основе выявления биотехнических закономерностей в изменении ширины годичных слоев (на кернах учетных деревьев) и колец (на спилах модельных деревьев) по радиусу и высоте ствола были получены более 50 патентов на изобретения мировой новизны. Выявление фундаментальных биотехнических закономерностей и поиск принципиально новых технических решений на их основе становится стратегией инновационного обучения бакалавров и магистров в области защиты окружающей природной среды и обустройства природных и природно-антропогенных объектов.

В основе нашей методологии заложен энергетический подход.

Энергоинформационный обмен активно протекает в дереве [17, 23].

По значениям ширины годичного слоя этот обмен можно измерять на различных уровнях исчисления:

1) точечном, когда измеряется число годичных слоев или колец только на одной высоте 1,3 м или 0,5 м (в данной статье) по последовательности номеров $i=1,2,3 \ldots$;

2) линейном, - по произвольному радиусу ствола на одной или различных высотах ствола выполняются замеры ширины годичного слоя или кольца $b>0$ мм;

3) плоскостном или поверхностном, причем в этом случае радиусы ствола для взятия кернов ориентируют по геодезическим направлениям, например, через $30^{\circ}$;

4) объемном, при котором одновременно измеряют размеры клеток [30], а также плотность, влажность и другие свойства древесины по годичным слоям (а также их частям) или же их группам.

\section{МЕТОДЫ И ОБЬЕКТЫ ИССЛЕДОВАНИЯ}

Метод кернов. Для изучения строения и свойств растущих деревьев без их разрушения применяют метод керна $[2,4,5]$. Керны древесины, извлекаемые из растущих деревьев при помощи возрастных и приростных буравов Пресслера, сохраняют все свойства дерева [1], что позволяет получить необходимые данные при исследованиях возрастной структуры, прироста по диаметру, структуры и плотности древесины отдельных деревьев и древостоев.

В практикуме [2] и статьях [18-22] изложены способы измерения ширины годичного слоя с точностью до 1 мкм, а также ширины поздней и ранней древесины, с использованием технологии ГИС.

Отбор кернов древесины проводился возрастным буравом фирмы Haglof на высоте 1,3 м у 10 дубов. В лабораторных условиях образцы были подготовлены к измерениям по общепринятой методике (Методы дендрохронологии, 2000). Ширина годичных колец измерялась с помощью полуавтоматического измерительного комплекса LINTAB с точностью до 0,01 мм.

По данным измерений строились графики абсолютного радиального прироста, которые использовались для точной датировки годичных слоев методом перекрестной датировки (Douglass, 1919).

Качество датировки оценивалось с помощью программы COFECHA (Holmes, 1995). Наличие ложных и выпадающих колец выявлялось в программе TSAPWin (Rinn, 2005).

Перекрестная датировка - это сравнение сходных графиков изменения ширины 
годичных слоев у разных деревьев и выбор точного места на кернах, где соответствие между ширинами максимально. Метод перекрестной датировки позволяет проводить относительную и абсолютную датировку времени формирования радиального прироста древесины у ствола по ширине годичных слоев.

Относительная датировка позволяет определить возраст анализируемых образцов относительно друг друга, для которых календарная дата не определена.

Абсолютная датировка определяет календарную дату годичных слоев на керне. Она выполняется в том случае, если известна календарная дата взятия образца древесины хотя бы у одного дерева [29].

Метод статистического моделирования. Проблема развития методов вариационного исчисления (23-я проблема Гильберта) до сих пор не разрешена, хотя в этом направлении много было сделано самим Гильбертом. Подробнее отдельные особенности нашей методологии даны в статье [15]. Технология пользования программной средой CurveExpert показана в пособии [27].

Идентификация по числовому полю или табличной модели имеет этапы:

1) эвристическая идентификация сути изучаемого явления или процесса по результатам измерений и анализа табличной модели (априорная информация) и осмысления в ходе выявления конструкции у однофакторной закономерности по её аддитивным составляющим (апостериорная информация);

2) структурная идентификация каждой однофакторной математической (статистической) функции как суммы инвариантов в виде асимметричных вейвлетсигналов с переменными амплитудой и периодом колебания;

3) параметрическая идентификация наращиваемой по отдельным инвариантам структуры устойчивой статистической закономерности в программной среде типа CurveExpert (http://www.curveexpert.net).

Идентификация эвристическая предполагает знание предмета исследования, поэтому здесь важен переход от физики к математике, а не наоборот. Мы давно отказались от методологии аппроксимации и, соответственно, вообще не применяем программы статистики из Excel. B идентификации первый этап (вариация функций) из теории аппроксимации исключается, - устойчивые законы заранее заданы как инварианты. Из них как из кирпичиков можно создавать различные математические конструкты. Использование в каждом конкретном примере статистического (вероятностного) моделирования того или иного устойчивого закона (по таблице 1 их всего семь) требует предварительного эвристического осмысления содержания задачи моделирования.

Вариация функций сводится к осознанному отбору устойчивых законов и конструированию на их основе волновых закономерностей.

Декарт предполагал существование одного-единственного алгебраического уравнения, пригодного как вариант решения для любых типов интегральных уравнений. Гильберт мечтал об инвариантах, из них как из кирпичиков будет собираться универсальное уравнение.

Они сгруппированы по принципу «от простого к сложному». По сути, фрагменты и сам биотехнический закон являются «кирпичиками Гильберта» для построения, в ходе процесса структурно-параметрической идентификации, аддитивной конструкции статистической модели с трендами и вейвлетами. Инварианты колебательных возмущений в виде асимметричных вейвлет-сигналов также включают в себя конструкты из таблицы 1 как амплитуда (половина) и полупериод.

В таблице 1 показаны наиболее встречающиеся инварианты (фрагменты). У них впереди могут быть расположены оперативные константы «+» или «-». Шесть устойчивых законов распределения являются частными случаями биотехнического закона, показанного внизу таблицы 1. 
Таблица 1. Математические конструкты (исходные инварианты или кирпичики Гильберта) для составления статистической модели

\begin{tabular}{|c|c|}
\hline $\begin{array}{c}\text { Фрагменты без предыстории } \\
\text { изучаемого явления или процесса }\end{array}$ & $\begin{array}{c}\text { Фрагменты с предысторией } \\
\text { изучаемого явления или процесса }\end{array}$ \\
\hline $\begin{array}{l}y=a x \text { - закон линейного роста или спада (при } \\
\text { отрицательном знаке перед правой стороной } \\
\text { формулы линейного изменения) }\end{array}$ & $\begin{array}{l}y=a \text { - закон не влияния принятой объясняющей } \\
\text { переменной на показатель, который имеет } \\
\text { собственную предысторию значений }\end{array}$ \\
\hline $\begin{array}{l}y=a x^{b} \text { - закон показательного роста (закон } \\
\text { показательной гибели } y=a x^{-b} \text { не является } \\
\text { устойчивым, из-за бесконечности значения } \\
\text { показателя при нулевом значении объясняющей } \\
\text { переменной) }\end{array}$ & $\begin{array}{l}y=a \exp ( \pm c x) \text { - закон Лапласа в математике } \\
\text { (Ципфа в биологии, Парето в экономике, } \\
\text { Мандельброта в физике) экспоненциального роста } \\
\text { или гибели, относительно которого } \\
\text { Лаплас создал методологию операторного } \\
\text { исчисления }\end{array}$ \\
\hline $\begin{array}{l}y=a x^{b} \exp (-c x) \text { - биотехнический закон в } \\
\text { упрощенной форме (П.М. Мазуркин), когда } \\
\text { показательный рост постепенно получает } \\
\text { экспоненциальное торможение }\end{array}$ & $\begin{array}{l}y=a \exp \left( \pm c x^{d}\right) \text { - закон экспоненциального } \\
\text { роста или гибели в полной форме (конструкции), } \\
\text { который имеет интенсивность, не равную единице } \\
\text { (П.М. Мазуркин) }\end{array}$ \\
\hline \multicolumn{2}{|c|}{$y=a x^{b} \exp \left(-c x^{d}\right)$ - биотехнический закон, общий для шести конструктов (П.М. Мазуркин) } \\
\hline
\end{tabular}

Устойчивые законы и закономерности на их основе делают выбор уравнения для последующей идентификации на статистических данных (числовых полях) вполне осмысленным, и поэтому вероятностное моделирование остается только при случайном поиске программной средой типа CurveExpert значений параметров у искомой модели. Поэтому из теории идентификации первый этап (выбор случайной структуры уравнения) исключается и остается только второй этап - случайная идентификация значений параметров модели.

Структура модели идентифицируется обработкой исходных данных так:

- вначале выявить детерминированные нелинейные закономерности;

- затем дополнять эти тренды колебательными возмущениями.

Идентификация параметрическая выполнялась в программной среде CurveExpert-1.40 (http://www.curveexpert.net) и информационной технологией идентификации пользуются студенты.

Процесс параметрической идентификации автоматически прекращается по условию достижения параметров модели некоторого минимального приращения и останавливается при достижении моделью погрешности измерений.

Метод вейвлет-анализа. Статистическая выборка - это многофакторное числовое поле в виде табличной модели. Этим определением она отличается от таблиц статистических изысканий. Причем необязательно все клетки таблицы должны быть заполненными.

При этом табличная модель необязательно имеет эвристические пояснения. Как правило, авторы измерений, приводя в своих публикациях таблицы данных, дают неверные содержательные толкования. Этот феномен эвристической формализации связан с тем, что таблица результатов измерений, даже если она составлена авторами правильно, не может быть содержательно осмыслена без проведения факторного анализа $[3,6,11]$ с математическим моделированием связей между парами факторов для выявления бинарных связей.

Тогда первичной становится табличная модель (исходное числовое поле), которая оценивается по погрешности проведенных измерений, а вторичным является искомое сложное алгебраическое уравнение (в смысле Декарта), составленное из инвариантов таблицы 1 (в смысле кирпичиков Гильберта). Этот процесс есть статистическая идентификация. Сама первообразная в виде неизвестного интегрального уравнения становится не нужным, хотя, может быть, кто-то и сумеет получать интегралы по нашим моделям.

Это - великое созидание, как уравнения Максвелла в электромагнетизме. 
Физико-математический подход предполагает понимание смысла динамического ряда как отражения какого-то составного процесса или же множества последовательно и параллельно происходящих природных и/или природноантропогенных процессов.

Тогда любое уравнение типа (3) можем записать как вейвлет-сигнал вида

$$
\begin{aligned}
y_{i} & =A_{i} \cos \left(\pi x / p_{i}-a_{8 i}\right), \\
A_{i}=a_{1 i} x^{a_{2 i}} \exp \left(-a_{3 i} x^{a_{4 i}}\right), p_{i} & =a_{5 i}+a_{6 i} x^{a_{7 i},}
\end{aligned}
$$

где $A_{i}$ - амплитуда (половина) вейвлета (ось $y$ ), $p_{i}$ - полупериод волны (ось $x$ ).

По формуле (1) с двумя фундаментальными физическими постоянными $e$ (число Непера или число времени) и $\pi$ (число Архимеда или число пространства) образуется изнутри изучаемого явления и/или процесса квантованный вейвлетсигнал. Понятие асимметричного вейвлет-сигнала позволяет абстрагироваться от физического смысла динамических рядов и рассматривать их аддитивное разложение.

В таблице 2 приведены интервалы изменения коэффициента корреляции как меры адекватности модели.

\begin{tabular}{|c|c|c|c|c|}
\hline \multirow[b]{2}{*}{$\begin{array}{c}\text { Интервал } \\
\text { коэффициента } \\
\text { корреляции }\end{array}$} & \multicolumn{4}{|c|}{ Характер тесноты связи между факторами } \\
\hline & $\begin{array}{l}\text { существующая } \\
\text { классификация }\end{array}$ & $\begin{array}{c}\text { шкала для } \\
\text { технических } \\
\text { измерений } \\
\end{array}$ & $\begin{array}{c}\text { шкала для } \\
\text { прецизионных } \\
\text { измерений } \\
\end{array}$ & $\begin{array}{c}\text { шкала для генной } \\
\text { инженерии и рядов целых } \\
\text { простых чисел }\end{array}$ \\
\hline 1 & \multirow{6}{*}{ сильная связь } & однозначная & однозначная & однозначная \\
\hline $0.999 \ldots 1000$ & & \multirow{4}{*}{ сильнейшая } & \multirow{2}{*}{ почти однозначная } & почти однозначная \\
\hline $0.99 \ldots 1.000$ & & & & чрезвычайно сильная \\
\hline $0.95 \ldots 0.99$ & & & сверхсильная & сверхсильная \\
\hline $0.90 \ldots 0.95$ & & & сильнейшая & сильнейшая \\
\hline $0.7 \ldots 0.9$ & & сильная & сильная & сильная \\
\hline $0.5 \ldots 0.7$ & \multirow{2}{*}{ слабая связь } & средняя & средняя & средняя \\
\hline $0.3 \ldots 0.5$ & & слабоватая & слабоватая & слабоватая \\
\hline $0.1 \ldots 0.3$ & \multirow{3}{*}{ нет связи } & слабая & Слабая & слабая \\
\hline $0.0 \ldots 0.1$ & & слабейшая & слабейшая & слабейшая \\
\hline 0 & & нет связи & нет связи & нет связи \\
\hline
\end{tabular}

Таблица 2. Уровни адекватности статистических моделей

Существующая шкала квантификации тесноты связи между принятыми факторами (нет связи, слабая и сильная связь) является очень грубой.

На первом месте располагаются математические объекты, например ряд простых чисел, у которых нет погрешностей. На втором месте находятся прецизионные измерения в астрономии, физике, технике и технологии. На третье место встают биологические объекты, и их поведение имеет четко проявляющийся колебательный характер, поэтому линейные и линеаризованные модели биологам вообще не подходят. Самые высокие погрешности имеют социально-экономические измерения.

Для многих природных (биологических) объектов и результатов прецизионных физических измерений пришлось ввести еще два интервала уровня адекватности по четвертому столбцу таблицы 2 , что нами было выполнено только при моделировании распределений рядов целых простых чисел. А для генной инженерии пришлось ввести еще один уровень адекватности, который был открыт для рядов целых простых чисел, то есть для чисто математических объектов, не имеющих погрешности измерений.

Объекты исследования. Популяция дубов естественного происхождения с 1850 г. За период в 165 лет, после проведения рубок, преобладающей породой стала липа. Поэтому учетные деревья дуба 10 шт. - это маленькие деревца с диаметром ствола до 50 см при высоте 18-21 м. Чтобы не потерять много годичных колец у таких деревьев керны отбирали на высоте 0,5 м от корневой шейки. В этом случае мы почти всегда попадали на продольную ось ствола.

Урочище «Святительская Гора» (рис. 1) расположено близ поселка Пановка (Высокогорский район Республики Татарстан). Широта 55.899444 (N), Долгота 


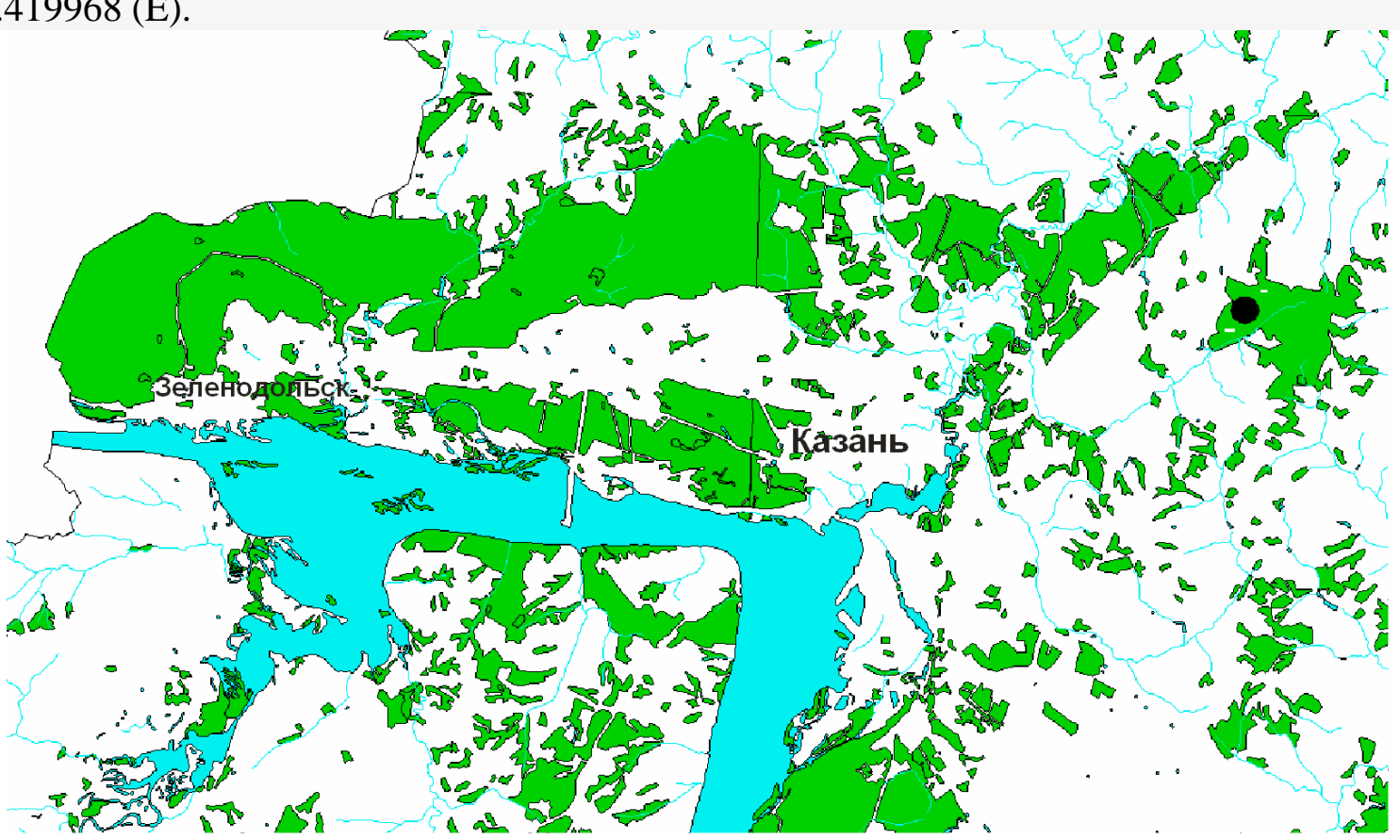

Рис. 1. Карта лесных массивов с указанием места расположения 10 учетных дубов

Обследованный выдел леса находится в кв. 134/135 Высокогорского лесничества. Рельеф приподнятый с абсолютными высотами 145-180 м. Почва серая лесная. Тип леса - липняк снытево-пролесниковый с содержанием дуба (6ЛЗД1Вед.Б).

В подлеске встречаются лещина обыкновенная, бересклет бородавчатый, клен остролистный и вяз шершавый. В травостое - сныть обыкновенная, осока волосистая и копытень европейский. Средний диаметр деревьев дуба - 40-50 см, а высота до 21 м, при этом возраст липы в среднем - 90 лет, дуба - 135 лет. Самому старому дубу 165 лет.

\section{РЕЗУЛЬТАТЫ ДЕНДРОХРОНОЛОГИЧЕСКИХ ИЗМЕРЕНИЙ}

Дендрохронологический анализ. Выбирается самое старое дерево и относительно его возраста устанавливается шкала времени. При этом учитывается возраст достижения дубами высоты в 0,5 м. поэтому в данных таблицы 3 приведены возрасты первых слоев керна (сердцевина ствола).

Семена имеют нулевую ширину годичного слоя $b$. Поэтому в таблице 3 напротив нулевого измеренного возраста $t_{u}=0$ у двух самых старых дубов поставлено значение $b=0$. При этом номера годичных слоев расставлены по методике [29]. Таким образом, принимается допущение, что популяция дубов началась с семян от 1854 г. (в дальнейшем моделированием вводится поправка на 4 года, а старт роста был с 1850 г.).

Таблица 3. Табличная модель для дендрохронологического анализа популяции из 10 дубов

\begin{tabular}{|c|c|c|c|c|c|c|c|c|c|c|c|c|}
\hline \multirow{2}{*}{$\begin{array}{c}\text { № } \\
\text { п/ா }\end{array}$} & \multirow{2}{*}{ Год } & \multirow{2}{*}{$\begin{array}{l}\text { Время } \\
t_{u}, \text { лет }\end{array}$} & \multicolumn{10}{|c|}{ Ширина годичного слоя $b\left(10^{2}\right.$ мм) по номерам учетного дуба } \\
\hline & & & №1 & №2 & №3 & №4 & №5 & №6 & №7 & №8 & №9 & №10 \\
\hline \multicolumn{3}{|c|}{ Возраст 1-го слоя } & 6 & 4 & 5 & 7 & 6 & 6 & 8 & 5 & 6 & 7 \\
\hline & & 0 & 0 & & & & & 0 & & & & \\
\hline & & 1 & & & 0 & & & & & & & \\
\hline & & 2 & & 0 & & & & & & & & \\
\hline & & 3 & & & & & 0 & & & & 0 & \\
\hline & & 4 & & & & & & & & & & \\
\hline & & 5 & . & & & & & & & & & \\
\hline 1 & 1860 & 6 & 83 & 109 & 43 & & & 75 & & & & \\
\hline 2 & 1861 & 7 & 70 & 95 & 54 & & & 73 & & & & \\
\hline
\end{tabular}




\begin{tabular}{|c|c|c|c|c|c|c|c|c|c|c|c|c|}
\hline 3 & 1862 & 8 & 118 & 136 & 50 & & & 96 & & & & \\
\hline 4 & 1863 & 9 & 79 & 110 & 25 & & 77 & 58 & & & 122 & \\
\hline 5 & 1864 & 10 & 63 & 95 & 30 & & 94 & 113 & & & 121 & \\
\hline$\ldots$ & $\ldots$ & $\ldots$ & $\ldots$ & $\ldots$ & $\ldots$ & $\ldots$ & $\ldots$ & $\ldots$ & $\ldots$ & $\ldots$ & $\ldots$ & $\ldots$ \\
\hline 23 & 1882 & 28 & 254 & 56 & 27 & & 199 & 268 & & & 84 & \\
\hline 24 & 1883 & 29 & 261 & 58 & 34 & 0 & 211 & 241 & 0 & & 108 & 0 \\
\hline 25 & 1884 & 30 & 231 & 66 & 33 & & 179 & 196 & & & 76 & \\
\hline 26 & 1885 & 31 & 224 & 45 & 28 & & 103 & 170 & & & 79 & \\
\hline 27 & 1886 & 32 & 255 & 31 & 115 & & 94 & 164 & & 0 & 81 & \\
\hline 28 & 1887 & 33 & 219 & 32 & 150 & & 189 & 279 & & & 186 & \\
\hline 29 & 1888 & 34 & 272 & 109 & 168 & & 205 & 287 & & & 240 & \\
\hline 30 & 1889 & 35 & 260 & 107 & 140 & & 209 & 206 & & & 209 & \\
\hline 31 & 1890 & 36 & 211 & 94 & 123 & 174 & 170 & 173 & & & 143 & 276 \\
\hline$\ldots$ & $\ldots$ & $\ldots$ & $\ldots$ & $\ldots$ & $\ldots$ & $\ldots$ & $\ldots$ & $\ldots$ & $\ldots$ & $\ldots$ & $\ldots$ & $\ldots$ \\
\hline 143 & 2002 & 148 & 66 & 66 & 86 & 25 & 52 & 93 & 69 & 76 & 60 & \\
\hline 144 & 2003 & 149 & 81 & 65 & 126 & 30 & 59 & 79 & 62 & 76 & 69 & \\
\hline 145 & 2004 & 150 & 104 & 80 & 140 & 36 & 61 & 130 & 84 & 75 & 73 & \\
\hline
\end{tabular}

Старт развитию и росту дубов № 1 и 6 начался с 1854 г. Меньшие по нулевому значения возраста особи дуба имеют ту же шкалу времени. Для повышения точности измерений нужны способы и средства для взятия кернов непосредственно от корневой шейки растущего дерева. Тогда погрешности начала исчисления возраста снизятся.

\section{РЕЗУЛЬТАТЫ И ОБСУЖДЕНИЕ ДИНАМИКИ ПРИРОСТА ПОПУЛЯЦИИ}

Bce 10 дубов были объединены в один массив данных (статистическую выборку) из 1328 пар значений $t_{u}$ и $b$ по данным таблицы 3. Идентификация параметрическая устойчивого закона в виде асимметричного вейвлет-сигнала (1) выполнялась в программной среде CurveExpert-1.40 (http://www.curveexpert.net).

Поведение 10 дубов. Вначале был идентифицирован биотехнический закон [723] и получена (рис. 2) формула

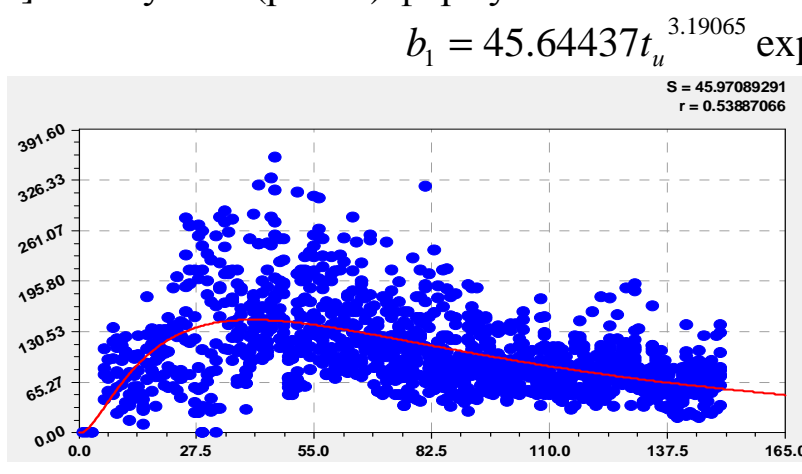

тренд (биотехнический закон)

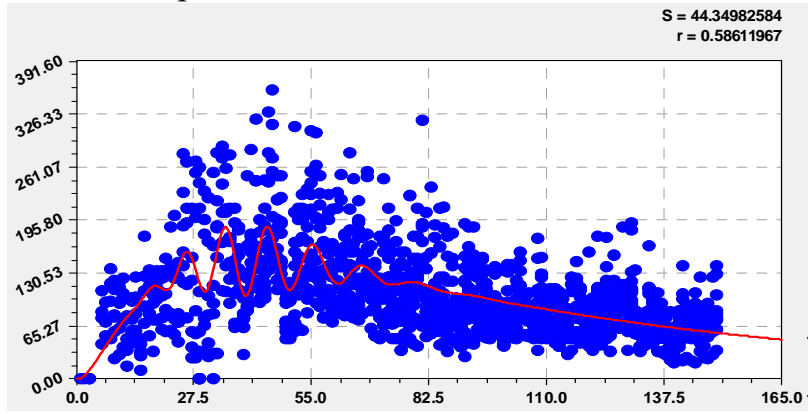

тренд и первое колебание $\exp \left(-3.50948 t_{u}^{0.29982}\right)$

$S=44.28550819$ $r=0.27341429$

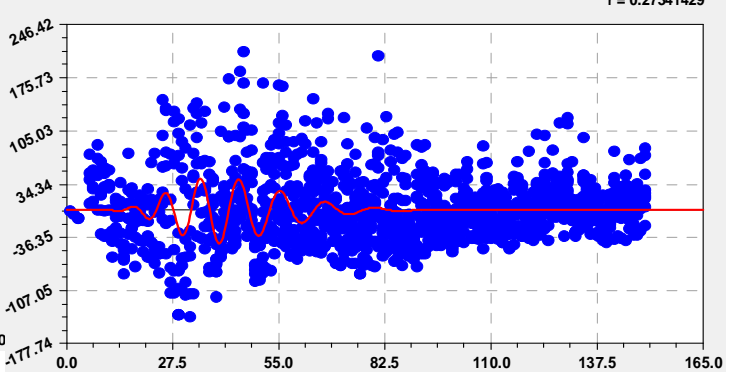
первое колебание

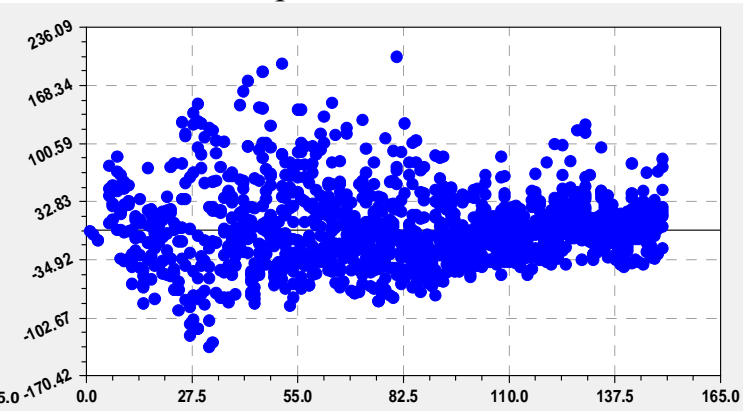

остатки после формулы (4)

Рис. 2. Графики отдельных составляющих (тренд и колебание) и общей закономерности динамики среднестатистической ширины годичного слоя у 10 дубов 
Затем по остаткам от модели (2) была получена волновая функция вида

$$
\begin{gathered}
b_{2}=A \cos \left(\pi t_{u} / p-1.45943\right), \\
A=5.95555 \cdot 10^{-9} t_{u}^{8.68284} \exp \left(-0.27849 t_{u}^{0.95116}\right), p=3.49986+0.017213 t_{u}^{0.99789} .
\end{gathered}
$$

После объединения формул (2) и (3) была получена (по известному эффекту уплотнения при встряске ящика для упаковки) статистическая модель (рис. 2) вида

$$
\begin{gathered}
b=b_{1}+b_{2}, \\
b_{1}=46,15411 t_{u}^{3,19167} \exp \left(-3,50974 t_{u}^{0,30005}\right), b_{2}=A \cos \left(\pi t_{u} / p-1.48083\right), \\
A=7.13613 \cdot 10^{-9} t_{u}^{8.62963} \exp \left(-0.28122 t_{u}^{0.94807}\right), p=3.49455+0.017294 t_{u}^{0.99747} .
\end{gathered}
$$

Коэффициент корреляции формулы (4) равен 0.5861, что относит это уравнение к группе факторных отношений по таблице 2 со средней теснотой связи.

Колебание радиального прироста во всей популяции из 10 дубов было в измеренном возрасте 20-80 лет, то есть хронологически в период с 1874 по 1934 гг. Для сопоставления нужны данные историографического анализа этого же лесного выдела.

По остаткам вейвлет-анализ далее был затруднен. Из-за этого модель (4) грубо характеризует поведение популяции дубов на лесном выделе. Затруднения возникли и при моделировании радиального прироста по отдельным дубам. Поэтому было решено косвенно проверить корректность начала развития и роста 10 дубов с 1854 г.

Установление общей шкалы времени. Возраст проростков дуба до высоты 0,5 м в 1854 г., то есть до высоты взятия кернов древесины в 2004 г., оценивается приближенно по росту молодых деревьев дуба в момент проведения измерений в 2004 г. Однако за период между двумя моментами времени (1854 и 2004 гг.) климат явно изменился. Кроме того, из-за антропогенного вмешательства в жизнь дубов (рубки деревьев влияют гораздо сильнее лесных пожаров) лесная среда также значительно изменилась. Чтобы повысить точность измерений начального возраста, в дальнейших опытах нужно брать керны древесины непосредственно с корневой шейки. Для этого нужны новые технические решения.

Для таблицы 3 предлагается следующая методика коррекции шкалы времени.

После идентификации была получена формула (сдвиг 3.5 года) вида

$$
b_{1}=1477.8720\left(t_{u}+3.48732\right)^{4.86310} \exp \left(-8.53220\left(t_{u}+3.48732\right)^{0.23434}\right) .
$$

Проверим гипотезу об ином начале развития и роста 10 дубов. Для этого в формулу тренда введем параметр сдвига начала координат в 4 года (начало шкалы с 1850 г.). Уточненная табличная модель при абсциссе $t=t_{u}+4$ приведена в таблице 4.

Таблица 4. Уточненная табличная модель для анализа популяции из 10 дубов

\begin{tabular}{|c|r|r|r|r|r|r|r|r|r|r|c|c|}
\hline Год & $t$, лет & №1 & №2 & №3 & №4 & №5 & №6 & №7 & №8 & №9 & №10 & $\sum$ \\
\hline 1860 & 10 & 83 & 109 & 43 & & & 75 & & & & & 310 \\
\hline 1861 & 11 & 70 & 95 & 54 & & & 73 & & & & & 292 \\
\hline 1862 & 12 & 118 & 136 & 50 & & & 96 & & & & & 400 \\
\hline 1863 & 13 & 79 & 110 & 25 & & 77 & 58 & & & 122 & & 471 \\
\hline 1864 & 14 & 63 & 95 & 30 & & 94 & 113 & & & 121 & & 516 \\
\hline$\ldots$ & $\ldots$ & $\ldots$ & $\ldots$ & $\ldots$ & & $\ldots$ & $\ldots$ & & & $\ldots$ & & $\ldots$ \\
\hline 1888 & 38 & 272 & 109 & 168 & & 205 & 287 & & & 240 & & 1281 \\
\hline 1889 & 39 & 260 & 107 & 140 & & 209 & 206 & & & 209 & & 1131 \\
\hline 1890 & 40 & 211 & 94 & 123 & 174 & 170 & 173 & & & 143 & 276 & 1364 \\
\hline 1891 & 41 & 193 & 105 & 64 & 127 & 123 & 129 & 210 & 69 & 106 & 146 & 1272 \\
\hline 1892 & 42 & 160 & 108 & 69 & 135 & 106 & 188 & 153 & 110 & 136 & 184 & 1349 \\
\hline$\ldots$ & $\ldots$ & $\ldots$ & $\ldots$ & $\ldots$ & $\ldots$ & $\ldots$ & $\ldots$ & $\ldots$ & $\ldots$ & $\ldots$ & $\ldots$ & $\ldots$ \\
\hline
\end{tabular}

В данных таблицы 4 шакалу времени измерений $t_{u}$ заменили на шкалу биологического времени $t$ с разницей назад по хронологии в 4 года. При этом был введен новый параметр годичных слоев: $\sum$ - суммарный радиальный прирост, $10^{2}$ мм. 


\section{РЕЗУЛЬТАТЫ И ОБСУЖДЕНИЕ ДИНАМИКИ СУММАРНОГО ПРИРОСТА}

Рассмотрим динамику радиального прироста с 1950 по 2004 гг. у дубов.

Закономерности поведения популяции дубов. Для анализа популяции введем новый параметр - суммарный радиальный прирост $\sum$ (по аналогии с суммой диаметров или суммой поперечных сечений стволов). Этот показатель, характеризующий общее поведение множества деревьев, показывает синергетический эффект радиального ежегодного прироста стволов дубов.

В 2004 г. на выделе было примерно 130 шт. деревьев на лесном земельном участке (выделе), из которых по формуле состава древостоя 7Л2Д1Вед.Б получаем $130 \times 0.2=26$ дубов. Тогда репрезентативность равна $10 \times 100 / 26=38.46 \%$.

После идентификации формулы (1) по возможностям программной среды CurveExpert-1.40 (рис. 3) была получена биотехническая закономерность вида

$$
\begin{gathered}
\sum=\sum_{1}+\sum_{2}+\sum_{3}+\sum_{4}, \\
\sum_{1}=2.26076 \cdot 10^{8} t^{9.61914} \exp \left(-23.71059 t^{0.18896}\right), \sum_{2}=A_{1} \cos \left(\pi t / p_{1}-2.38838\right), \\
A_{1}=105.83628 t^{0.32149} \exp \left(-0.036995 t^{0.76111}\right), p_{1}=13.85309+0.059424 t^{1.14642}, \\
\sum_{3}=A_{2} \cos \left(\pi t / p_{2}-0.029723\right), A_{2}=-6.04581 \cdot 10^{-150} t^{113.17000} \exp \left(-1.15177 t^{1.12275}\right), \\
p_{2}=0.12612+0.019464 t^{0.93311}, \sum_{4}=A_{3} \cos \left(\pi t / p_{3}-4.07504\right), \\
A_{3}=-12.74941 t^{0.87846} \exp \left(-0.041859 t^{0.89853}\right), p_{3}=1.38379+0.0016583 t^{1.10608}
\end{gathered}
$$

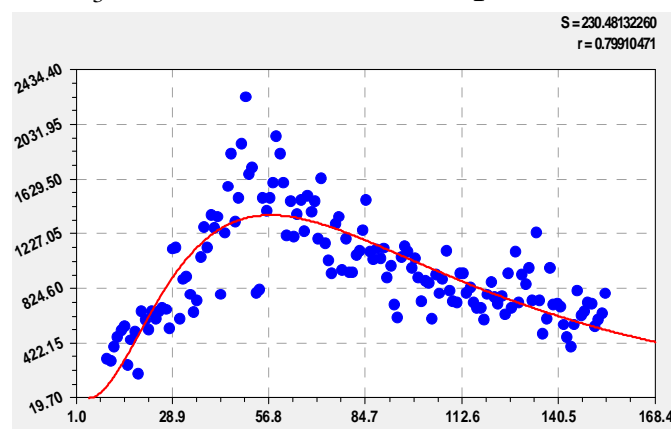

тренд (биотехнический закон)

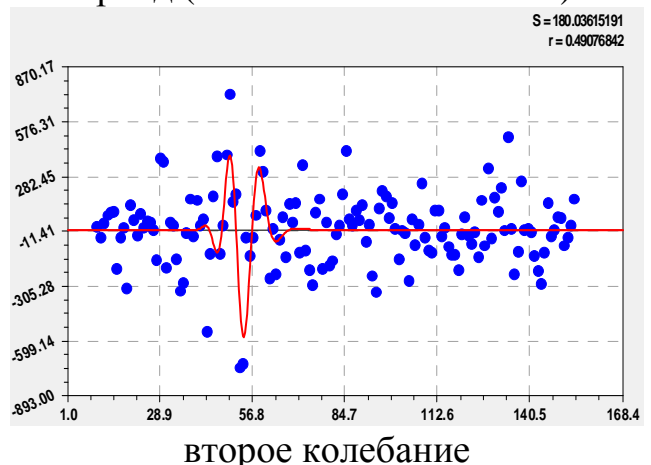

второе колебание

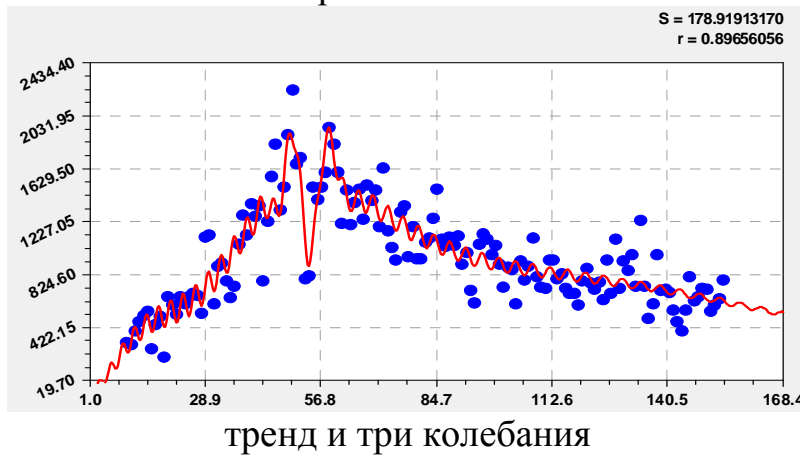

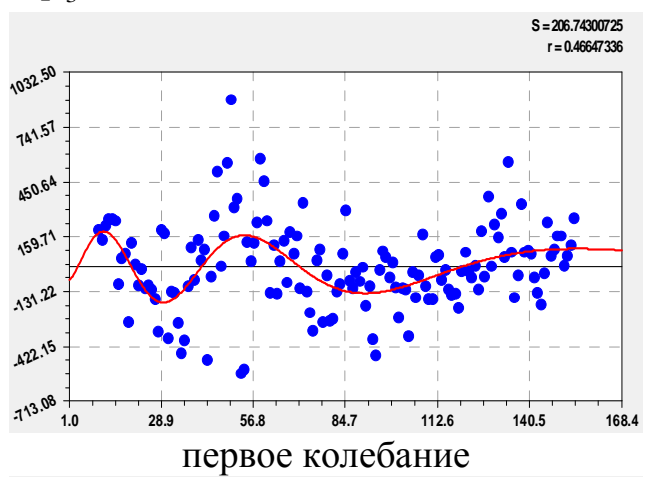
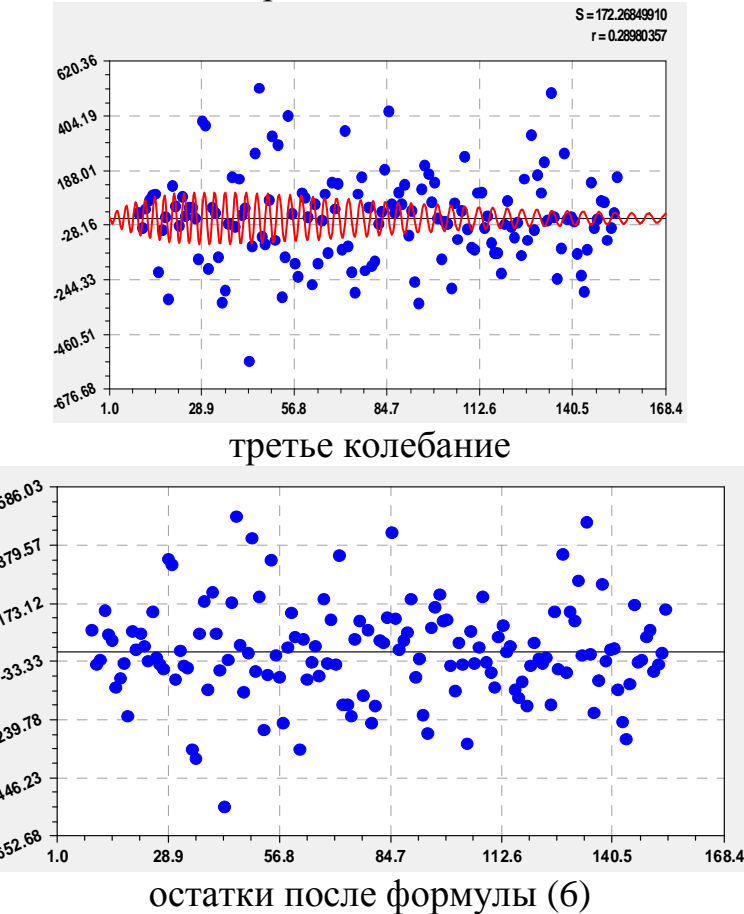

Рис. 3. Графики отдельных составляющих (тренд и три колебания) и общей закономерности динамики среднестатистической суммарной ширины годичного слоя у популяции из 10 дубов 
Коэффициент корреляции формулы (6) равен 0.8966, что по классификации из таблицы 2 относит её к сильнейшим факторным связям. Из рисунка 3 видно, что даже тренд имеет адекватность 0.7991 (сильная теснота связи), поэтому тенденция пригодна для расчетов. По ней видно, что максимум суммарной ширины годичных слоев у популяции приходится на возраст примерно 56-58 лет, то есть на период 1906-1908 гг.

В дальнейшем по тренду активность радиального роста дубов снижается.

По сути [10-12, 16, 22], тренд есть часть волны с полупериодом, много большим периода измерений в 154 года. Остальные колебания имеют полупериод, меньший полтора века. Поэтому растения приспосабливаются к изменениям в окружающей среде (точнее, к внешним воздействиям в виде сигналов) волновой адаптацией своего поведения. Эти сигналы волновой адаптации отображаются в динамике годичного прироста. Для радиального прироста характерно, что популяция в целом через суммарную ширину годичных слоев дает возможность идентифицировать вейвлетсигналы гораздо лучше, чем эта же ширина у отдельных особей.

Например, три волны по графикам на рисунке 3 имеют нарастающий полупериод, который показывает снижение частоты колебания, т.е. дубы с момента возникновения со временем успокаиваются. При этом первая волна продолжится и после 2004 г., а вторая и третья волны уже произошли в периоде измерений с 1850 по 2004 гг.

Наиболее характерна вторая волна колебательного возмущения. Такие импульсные функции на коротком отрезке времени происходит из-за какого-то стресса. Исторических данных об этом лесном выделе у нас нет, поэтому можно только предположить, что было катастрофическое влияние (например. вырубили соседей) на жизнь дубов. Начальный период колебания при условии $t=0$ (для 1850 г.) имеет четкий физический смысл.

Всего было получено 104 членов общей модели типа формулы (6). Для её компактной записи по параметрам модели применим матричную форму (табл. 5).

Период начального старта проростков у дубов 28,4 года чуть больше цикла вращения ядра Солнца вокруг своей оси. Большинство волновых членов из таблицы 5 начинаются с цикла (полвины или четверти цикла в 11,3 года) солнечной активности. Вторе колебание в формуле (6) начинается с периода в 0,25 года (сезон года), а третья волна стартует с 2,76 года (четверть периода солнечной активности, то есть эффекта А.Л. Чижевского [7]).

Таблица 5. Параметры уравнения динамики суммарного годичного радиального прироста дубов

\begin{tabular}{|c|c|c|c|c|c|c|c|c|c|}
\hline \multirow{3}{*}{$\begin{array}{l}\text { Но- } \\
\text { мер } \\
i\end{array}$} & \multicolumn{8}{|c|}{ Асимметричный вейвлет $\sum_{i}=a_{1 i} t^{a_{2 i}} \exp \left(-a_{3 i} t^{a_{4 i}}\right) \cos \left(\pi t /\left(a_{5 i}+a_{6 i} t^{a_{7 i}}\right)-a_{8 i}\right)$} & \multirow{3}{*}{$\begin{array}{c}\text { Коэфф } \\
\text { коррел } \\
r\end{array}$} \\
\hline & \multicolumn{4}{|c|}{ амплитуда (половина) колебания } & \multicolumn{3}{|c|}{ полупериод колебания } & \multirow{2}{*}{\begin{tabular}{|c|c} 
сдвиг \\
$a_{8 i}$
\end{tabular}} & \\
\hline & \begin{tabular}{ll|l}
$a_{1 i}$ & \\
\end{tabular} & $a_{2 i}$ & $a_{3 i}$ & $a_{4 i}$ & $a_{5 i}$ & $a_{6 i}$ & $a_{7 i}$ & & \\
\hline 1 & $2.26076 \mathrm{e} 8$ & 9.61914 & 23.71059 & 0.18896 & 0 & 0 & 0 & 0 & \multirow{4}{*}{0.9866} \\
\hline 2 & 105.83628 & 0.32149 & 0.036995 & 0.76111 & 13.85309 & 0.059424 & 1.14642 & 2.38838 & \\
\hline 3 & $-6.04581 \mathrm{e}-150$ & 113.17000 & 1.15177 & 1.12275 & 0.12612 & 0.019464 & 0.93311 & 0.029723 & \\
\hline 4 & \begin{tabular}{|l|}
-12.74041 \\
\end{tabular} & 0.87846 & 0.041859 & 0.89853 & 1.38379 & 0.0016583 & 1.10608 & 4.07504 & \\
\hline 5 & -0.047557 & 1.94673 & 0.0014659 & 1.51283 & 5.57846 & -1.87814 & 0.048768 & $\mid-3.76447$ & 0.2573 \\
\hline 6 & $6.59042 \mathrm{e}-130$ & 85.82931 & 0.99831 & 0.98387 & 35.39857 & -0.22548 & 0.99953 & -1.96599 & 0.3055 \\
\hline 7 & $2.58702 \mathrm{e}-10$ & 8.33767 & 0.0022123 & 1.97491 & 0.88592 & 0.019960 & 0.88332 & 3.20839 & 0.4573 \\
\hline 8 & $1.60063 \mathrm{e}-123$ & 67.72370 & & 1.57029 & 42.62108 & -0.33582 & 0.84007 & -0.36538 & 0.3029 \\
\hline 9 & 0.5 & & & 1.57 & & & 1.86098 & -1.86 & 0.2637 \\
\hline 10 & $8.43203 e-5$ & 9.93984 & 3.70663 & 0.48774 & 4.61720 & -0.0039394 & 1.12942 & 2.67988 & 0.3690 \\
\hline 11 & $-3.07466 \mathrm{e}-28$ & 19.11180 & 0.098669 & 1.16577 & 4.91432 & 0.00090799 & 1.70058 & -5.79682 & 0.1627 \\
\hline 12 & $1.42564 \mathrm{e}-27$ & 31.65520 & 3.08219 & 0.76082 & 2.36953 & 0 & 0 & 4.52103 & 0.2194 \\
\hline 13 & $-1.29159 y-21$ & 14.86157 & 0.0050962 & 1.81226 & 4.76771 & 0 & 0 & 4.37355 & 0.1634 \\
\hline 14 & $-2.37874 e-63$ & 35.37397 & 0.010719 & 1.57977 & 1.02646 & 0 & 0 & -1.32645 & 0.2929 \\
\hline 15 & $4.67537 \mathrm{e}-23$ & 72.85903 & 71.81842 & 0.29665 & 1.10141 & 0 & 0 & -1.55077 & 0.3922 \\
\hline 16 & $8.69729 \mathrm{e}-145$ & 85.91174 & 0.63329 & 1 & 1.44139 & 0 & 0 & 4.00260 & 0.2026 \\
\hline 17 & $3.99512 \mathrm{e}-22$ & 14.03345 & 0.11915 & 1 & 2ю65516 & $-3.01501 \mathrm{e}-9$ & 1 & \begin{tabular}{|l|l|}
0.87317 \\
\end{tabular} & \begin{tabular}{|l|l|}
0.1634 \\
\end{tabular} \\
\hline 18 & $1.88471 \mathrm{e}-44$ & 33.17049 & 0.56815 & 1 & 1.32677 & 0.0093358 & 0.80026 & 0.25630 & 0.3247 \\
\hline
\end{tabular}




\begin{tabular}{|c|c|c|c|c|c|c|c|c|c|}
\hline \multirow{3}{*}{$\begin{array}{l}\text { Ho- } \\
\text { мep } \\
i\end{array}$} & \multicolumn{8}{|c|}{ Асимметричный вейвлет $\sum_{i}=a_{1 i} t^{a_{2 i}} \exp \left(-a_{3 i} t^{a_{4 i}}\right) \cos \left(\pi t /\left(a_{5 i}+a_{6 i} t^{a_{7 i}}\right)-a_{8 i}\right)$} & \multirow{3}{*}{$\begin{array}{c}\text { Коэфф. } \\
\text { коррел. } \\
r\end{array}$} \\
\hline & \multicolumn{4}{|c|}{ амплитуда (половина) колебания } & \multicolumn{3}{|c|}{ полупериод колебания } & \multirow{2}{*}{$\begin{array}{c}\text { сдВиг } \\
a_{8 i}\end{array}$} & \\
\hline & $a_{1 i}$ & $a_{2 i}$ & $a_{3 i}$ & $a_{4 i}$ & $a_{5 i}$ & $a_{6 i}$ & $a_{7 i}$ & & \\
\hline 19 & $2.98820 \mathrm{e}-72$ & 41.61667 & 0.26026 & 1 & 1.92396 & $-1.63807 \mathrm{e}-6$ & 1 & 5.69894 & 0.3384 \\
\hline 20 & -278.50159 & 0.018776 & & 0.81160 & & -0.0055814 & 0.72375 & 5.43415 & \\
\hline 21 & $2.26400 \mathrm{e}-43$ & 35.09205 & 0.38202 & 1.15897 & 4.43338 & -0.015833 & 1.03155 & $\mid-4.86187$ & 1279 \\
\hline 22 & $3.31528 \mathrm{e}-29$ & 16.85374 & 0.095402 & 1 & 7.77715 & -0.014744 & 1.00132 & -4.77745 & 3176 \\
\hline 23 & $5.24074 \mathrm{e}-9$ & 6.10282 & 0.062552 & 0.98007 & 4.44939 & -0.0032951 & 1.07113 & -3.62876 & 0.1788 \\
\hline 24 & -7925.4765 & 3.29333 & 15.63897 & 0.24750 & 2.22612 & -0.69672 & 0.11400 & $\mid-2.30140$ & 0.3598 \\
\hline 25 & 1.19082 & & 1.44794 & 0.47816 & 0.97615 & 0 & 0 & 2.95301 & 0.1544 \\
\hline 26 & $2.82138 \mathrm{e}-46$ & 27.4 & 0.17088 & 22 & 1.09 & 0 & 0 & & \\
\hline 27 & $6.27995 \mathrm{e}-12$ & 28.1 & 28.19124 & & 39 & 0 & 0 & \begin{tabular}{|l|}
1.26733 \\
\end{tabular} & 4637 \\
\hline 28 & $45036 \mathrm{e}-41$ & & 51672 & & & 0.00026125 & 1 & & 5314 \\
\hline 29 & $1.22726 \mathrm{e}-41$ & 27.72228 & 0.28748 & 1.00192 & 1.27736 & $1.38859 \mathrm{e}-5$ & 0.93807 & 3.88126 & 5743 \\
\hline 30 & $-4.90257 \mathrm{e}-27$ & 15.61369 & 0.0063452 & 1.54549 & 1.75108 & 0 & 0 & |-1.09824 & 0.4004 \\
\hline 31 & $-1.08184 \mathrm{e}-123$ & 81.97593 & 0.90677 & 1.00017 & 1.45213 & $-2.18779 e-6$ & 1 & 4.27520 & 0.3720 \\
\hline 32 & $-4.61805 e-103$ & & & & & & 1.05057 & & \\
\hline 33 & e-7 & & & & & -0. & 0.71847 & -2.11 & \\
\hline 34 & $4.91974 \mathrm{e}-68$ & 51.0 & 40696 & 48 & & 0 & 0 & \begin{tabular}{|l|}
0.88164 \\
\end{tabular} & 101 \\
\hline 35 & 3.696 & 36. & 40.94110 & 0.27323 & & $\mathrm{c}$ & 0 & 2.42461 & 2843 \\
\hline 36 & & & 0.094259 & 1 & & 0 & 0 & $\mid-1.02618$ & 2881 \\
\hline 37 & & & 0 & 0 & & -0.0046625 & 1.04662 & $\mid-2.71458$ & 4180 \\
\hline 38 & $2.31487 \mathrm{e}-21$ & & & 1.00739 & & & 1.49994 & & \\
\hline 39 & -2.31 & & & 1 & & & 1 & & \\
\hline 40 & $e-22$ & 15. & 38729 & 0.84898 & & -0.01 & \begin{tabular}{|l|}
0.94847 \\
\end{tabular} & -1.35300 & 3607 \\
\hline 41 & 950 & 249 & 0 & 0 & 1.20095 & $1.00822 \mathrm{e}-7$ & 1 & \begin{tabular}{|l|}
0.47721 \\
\end{tabular} & 2985 \\
\hline 42 & 5428 & & 1.46621 & 0.47063 & & 0 & 0 & & 3122 \\
\hline 43 & $-3.22445 \mathrm{e}-13$ & 8.95 & 0.048954 & 1.15817 & & 0.0016221 & 1.06770 & 3.51620 & 0.3908 \\
\hline 44 & $-9.02307 e-5$ & & & & & 0 & 0 & \begin{tabular}{|l|}
-1.81253 \\
\end{tabular} & 0.2401 \\
\hline 45 & & & & & & 0.2530 & 0.38698 & & \\
\hline 46 & $9 \mathrm{e}-7$ & & 0.00 & & & 0 & 0 & & 2212 \\
\hline 47 & $\mathrm{e}-31$ & 21.4 & 24871 & 1.00735 & & -0.00049162 & 1.17610 & -0.24886 & 3743 \\
\hline 48 & 617 & & 0 & 0 & & $-6.24316 \mathrm{e}-5$ & \begin{tabular}{|l|}
1 \\
\end{tabular} & $\mid-0.62060$ & 2085 \\
\hline 49 & -0.00 & & 0.010369 & 1.00045 & & 3.2568 & 1 & \begin{tabular}{|l|}
0.17717 \\
\end{tabular} & 0.3303 \\
\hline 50 & & & 2481 & 815 & & 0.042554 & 0.58125 & \begin{tabular}{|l|}
3.75380 \\
\end{tabular} & 0.3315 \\
\hline 51 & $989 \mathrm{e}-11$ & & & 1.84 & & 0 & 0 & & \\
\hline 52 & & & & 1 & & 02058 & 1 & & \\
\hline 53 & -14 & & $4 e-5$ & .90111 & 2.84 & 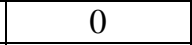 & 0 & -3.60775 & 468 \\
\hline 54 & 598 & & 788 & 0.96463 & 28.60040 & 0.25912 & .84933 & \begin{tabular}{|c|}
-4.21863 \\
\end{tabular} & 2555 \\
\hline 55 & e-24 & & & 556 & 30. & 0.2903 & 0.83748 & \begin{tabular}{|l|l|}
5.58391 \\
\end{tabular} & 3115 \\
\hline 56 & $4.97554 \mathrm{e}-16$ & 23.28094 & 121 & 0.62678 & 1.68155 & 0 & 0 & -3.51396 & 0.2364 \\
\hline 57 & & & & 1 & & $-6.73970 \mathrm{e}-10$ & 1 & -4.62020 & 2231 \\
\hline 58 & & & & & & 0 & 0 & & 2207 \\
\hline 59 & $e-18$ & & & & & 023386 & 0.98511 & \begin{tabular}{|l|}
4.37118 \\
\end{tabular} & 2085 \\
\hline 60 & & & 286 & & & 0.0131 & 0.82108 & -1.36221 & 1859 \\
\hline 61 & 7822 & 580 & 252 & 0.00041976 & 403 & 0 & 0 & \begin{tabular}{|l|}
1.53798 \\
\end{tabular} & 1275 \\
\hline 62 & $-2.26210 e-78$ & 61.27361 & 0.60200 & 1.17038 & 1.12735 & 0.00062443 & 1 & $\mid-1.28179$ & 0.4095 \\
\hline 63 & $2.94455 \mathrm{e}-9$ & & & 73222 & 0.66914 & 0.00015527 & 1.45741 & 0.51506 & 0.1183 \\
\hline 64 & $2.52153 \mathrm{e}-24$ & & & & & -0.00024040 & 1 & \begin{tabular}{|l|}
-5.96479 \\
\end{tabular} & 0.1673 \\
\hline 65 & & & & & & 0 & 0 & \begin{tabular}{|l|}
1.33048 \\
\end{tabular} & 0.2769 \\
\hline 66 & & & & & & c & 0 & \begin{tabular}{|l|}
0.56576 \\
\end{tabular} & 0.1847 \\
\hline 67 & $28319 \mathrm{e}-45$ & 30.27852 & & 9486 & 88379 & 0 & 0 & 2.05820 & 0.5053 \\
\hline 68 & $-3.03550 \mathrm{e}-54$ & 52.88801 & 1.84682 & 0.99683 & 1.42813 & -0.0088740 & 0.91965 & $|-0.82758|$ & 0.2119 \\
\hline 69 & $-4.34328 \mathrm{e}-15$ & 12.01150 & 0.31020 & 0.94916 & 2.86675 & -0.010226 & 0.71232 & -4.38942 & 0.2265 \\
\hline 70 & $1.00820 \mathrm{e}-39$ & 23.91523 & 0.17201 & 1.02034 & 1.26107 & 0 & 0 & \begin{tabular}{|c|}
-0.11673 \\
\end{tabular} & 0.6292 \\
\hline 71 & $4.53948 \mathrm{e}-112$ & 73.56014 & 0.16638 & 1.36206 & 1.23829 & 0 & 0 & $\mid-5.41753$ & 0.4169 \\
\hline 72 & $-8.35607 e-9$ & & 0.051999 & 1 & 1.10278 & 0 & 0 & 0.38331 & 0.2272 \\
\hline 73 & $2.14302 \mathrm{e}-33$ & & 0.0033681 & & & 0 & 0 & -2.51149 & 0.7054 \\
\hline 74 & $-1.77178 \mathrm{e}-48$ & & & & & 0 & 0 & -0.20305 & 0.5736 \\
\hline 75 & $-3.35938 \mathrm{e}-17$ & 13.22422 & 0.25366 & 0.99916 & 1.89097 & $-8.00071 \mathrm{e}-5$ & 1.20795 & \begin{tabular}{|l|l|}
5.08396 \\
\end{tabular} & 0.5572 \\
\hline
\end{tabular}




\begin{tabular}{|c|c|c|c|c|c|c|c|c|c|}
\hline \multirow{3}{*}{$\begin{array}{l}\text { Но- } \\
\text { мер } \\
i\end{array}$} & \multicolumn{8}{|c|}{ Асимметричный вейвлет $\sum_{i}=a_{1 i} t^{a_{2 i}} \exp \left(-a_{3 i} t^{a_{4 i}}\right) \cos \left(\pi t /\left(a_{5 i}+a_{6 i} t^{a_{7 i}}\right)-a_{8 i}\right)$} & \multirow{3}{*}{$\begin{array}{c}\text { Коэфф. } \\
\text { коррел. } \\
r\end{array}$} \\
\hline & \multicolumn{4}{|c|}{ амплитуда (половина) колебания } & \multicolumn{3}{|c|}{ полупериод колебания } & \multirow{2}{*}{\begin{tabular}{|c|} 
сдвиг \\
$a_{8 i}$
\end{tabular}} & \\
\hline & $a_{1 i}$ & $a_{2 i}$ & $a_{3 i}$ & $a_{4 i}$ & $a_{5 i}$ & $a_{6 i}$ & $a_{7 i}$ & & \\
\hline 76 & $-1.26147 \mathrm{e}-15$ & 20.01589 & 1.33104 & 0.98413 & 2.08375 & -0.032040 & 0.93968 & -2.57662 & 0.2309 \\
\hline 77 & $2.43398 \mathrm{e}-111$ & 74.95642 & 0.91615 & 1 & 0.54443 & -4.10812 & -0.24184 & 0.52169 & 0.2807 \\
\hline 78 & -0.00029743 & 2.086 & 0.023 & 1 & 1.19486 & 0 & 0 & -0.54954 & 0.1794 \\
\hline 79 & $-9.70863 e-23$ & 17.09907 & 40 & 0.98115 & 1.04354 & 0 & 0 & -3.25039 & 0.1709 \\
\hline 80 & $-1.91969 \mathrm{e}-6$ & 6.40727 & 204 & 0.82 & 0.081217 & 0.011602 & 1.06031 & 5.84257 & 0.2448 \\
\hline 81 & $1.16800 \mathrm{e}-7$ & 3.84372 & 738 & 0.662 & 1.31779 & 0.038478 & 1.01171 & 3.31154 & 0.1129 \\
\hline 82 & $-6.38794 \mathrm{e}-41$ & 24.30473 & 0.11519 & 1.11541 & 2.54349 & 0 & 0 & -1.33904 & 0.2592 \\
\hline 83 & $-1.99072 \mathrm{e}-5$ & 2.32830 & 0 & 0 & 1.65914 & 0 & 0 & 2.04174 & 0.6371 \\
\hline 84 & $-6.87800 e-27$ & 37. & 2.19733 & 1.07472 & & 0.0066515 & 1.15194 & 0.86619 & 0.1889 \\
\hline 85 & $-8.09292 \mathrm{e}-10$ & & 51 & 0.48036 & 1.06 & 0 & 0 & -0.28 & 0.3833 \\
\hline 86 & $-8.14394 e-8$ & 6.12117 & 21127 & 0.91656 & 1.69044 & -0.0026989 & 1.05467 & -4.88319 & 0.4266 \\
\hline 87 & 7.046 & 66.8 & 46688 & 1.01275 & 15.0 & -0.048 & 1.06930 & -5.1 & 4457 \\
\hline 88 & 0.027673 & 0.310 & 0 & 0 & 21.93606 & 0.0010328 & 1.80269 & 3.70354 & 0.1051 \\
\hline 89 & $-4.12337 e-5$ & 2.67215 & 0.20693 & 0.57924 & 0.81664 & $\begin{array}{l}0 \\
\end{array}$ & 0 & -4.55601 & 0.4232 \\
\hline 90 & & & & 1 & & $-3.75593 e-6$ & 1 & & 0.3723 \\
\hline 91 & 2.526 & 41.2 & 73 & 1.00296 & & -0.0014139 & 1.13656 & -1.87 & 0.4438 \\
\hline 92 & $-5.38091 \mathrm{e}-6$ & 7.17880 & 2.29914 & 0.50798 & 2.18699 & 0 & 0 & 4.23711 & 0.3703 \\
\hline 93 & $-8.08037 \mathrm{e}-14$ & 10.64 & 246 & 0.89365 & 6.22397 & -0.031553 & 1.00690 & -2.65404 & \begin{tabular}{|l|}
0.4296 \\
\end{tabular} \\
\hline 94 & $7.92565 \mathrm{e}-35$ & 26.89983 & 0.49694 & 1.02598 & 1.14681 & 0 & 0 & -3.93675 & 0.2574 \\
\hline 95 & $-7.79773 \mathrm{e}-25$ & 12.82981 & 0.057942 & 1.02130 & 11.33891 & -0.0078372 & 0.98366 & 0.018248 & 0.2800 \\
\hline 96 & $-6.97805 e-9$ & 5.20050 & 0.50315 & 0.57092 & 2.84282 & 0 & 0 & -2.34075 & 0.2497 \\
\hline 97 & 0.044149 & & & & & 0 & 0 & \begin{tabular}{|l|}
4.19789 \\
\end{tabular} & 0.4006 \\
\hline 98 & $-8.57545 e-16$ & 26.861 & 9.573 & 0.53026 & 0.59424 & 0 & 0 & 1.79516 & 0.2122 \\
\hline 99 & $1.09941 \mathrm{e}-27$ & 17.08013 & 0ю23160 & Ою93637 & 1.22862 & 0 & 0 & -6.09109 & 0.5971 \\
\hline 100 & 0.0013710 & 1.59757 & 0.00091187 & 1.77032 & 0.72365 & 0 & 0 & 4.09151 & 0.4267 \\
\hline 101 & $-1.89714 \mathrm{e}-15$ & 9.87194 & 0.14743 & 0.98494 & 1.37791 & 0 & 0 & -1.28963 & 0.2973 \\
\hline 102 & $8.10667 \mathrm{e}-19$ & 10.58796 & 0.054469 & 1.10461 & 3.37314 & 0.00033785 & 1 & -4.88687 & \begin{tabular}{|l|l|}
0.3361 \\
\end{tabular} \\
\hline 103 & $-1.54402 \mathrm{e}-5$ & 4.04419 & 1.58928 & 0.39857 & 3.92159 & 0 & 0 & 3.50976 & 0.2186 \\
\hline 104 & $-5.52104 \mathrm{e}-30$ & 18.63608 & 0.22517 & 0.97597 & 1.85412 & 0.0016044 & 1 & -6.08052 & \begin{tabular}{|l|}
0.3217 \\
\end{tabular} \\
\hline
\end{tabular}

Сдвиг волны в трех колебаниях одинаков и показывает, что начало возникновения проростков дуба находится гораздо раньше 1850 г. По первому колебанию получим сдвиг на $2.28838 \times 13.85309 /(2 \pi)=5.0454$ года. Поэтом колебание популяции началось с $1850-5=1845$ года. По-видимому, это есть истинное начало популяции.

Процесс идентификации был остановлен по достижении точности измерений ширины годичного слоя на 10 кернах. При этом цена деления из таблиц 3 или 4 равна 10 мкм (микрон). Тогда погрешность измерений будет равна \pm 5 мкм (или $0.5 \times 10^{2}$ мм). Остатки после 104-ого члена общей модели по значениям его параметров из данных таблицы 5 стали меньше $\pm 0.5 \times 10^{2}$ мм. Поэтому можно сделать вывод о том, что вейвлет-анализ динамики суммарной ширины годичных слоев у популяции выполнен.

Условно можно выделить три этапа в поведении дубов: I - 0 ... 60 лет или с 1850 по 1910 гг.; II - 25 . . 110 лет или с 1875 по 1960 гг.; III - 70 . . 154 года или с 1930 по 2004 гг. Относительно трех этапов расположились сквозные вейвлеты (номера из табл. 5) общей динамика суммарного радиального прироста дубов 1850-2004 гг.

Вейвлет-сигналы общей динамики поведения дубов. В эту группу попали номера следующих составляющих из таблицы 5: 1, 2, 4, 5, 24, 37, 42, 50, 60, 61, 78, 88, 89, 97, 103. Все 15 графиков приведены на рисунке 4.

По тренду можно проследить среднестатистическую линию поведения популяции из 10 дубов и прогнозировать изменение суммарной ширины годичных слоев до 2135 года, когда $\sum_{1}=1.00$ мм. Максимум по тренду был равен 13.74 мм в 1907 году (фактическое значение 14.91 мм) в возрасте 57 лет (относительная погрешность максимума всего $7.86 \%)$. 


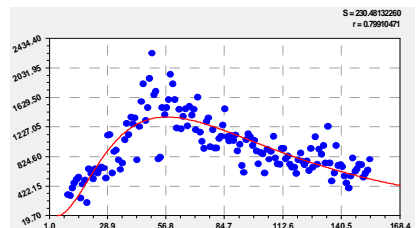

первая составляющая

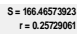

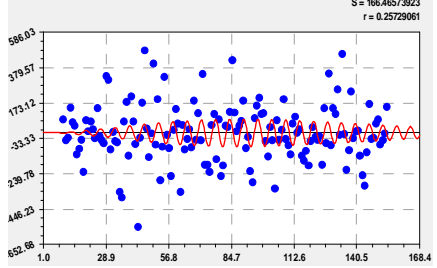

пятая составляющая

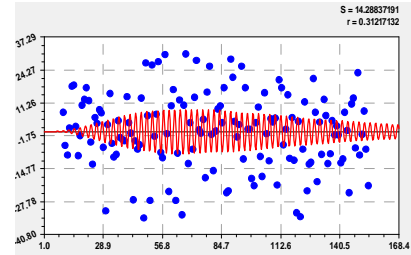

42-ая составляющая

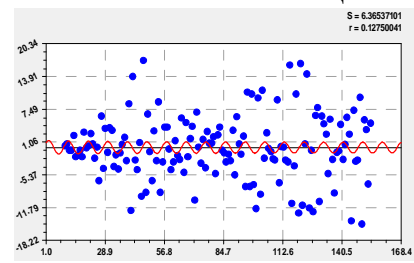

61-ая составляющая

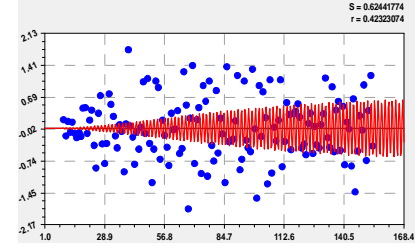

89-ая составляющая

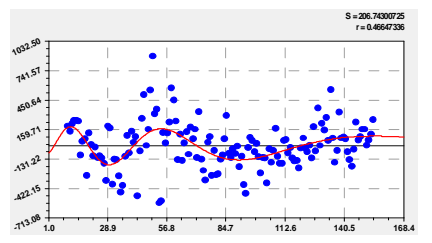

вторая составляющая

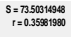

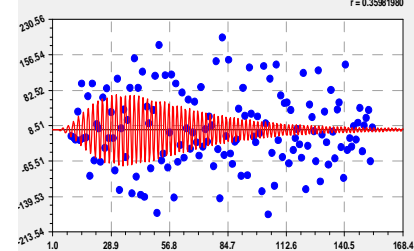

24-ая составляющая

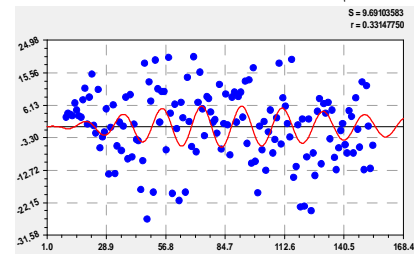

50-ая составляющая

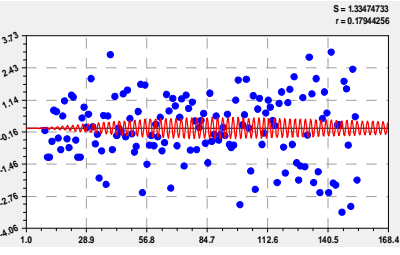

78-ая составляющая

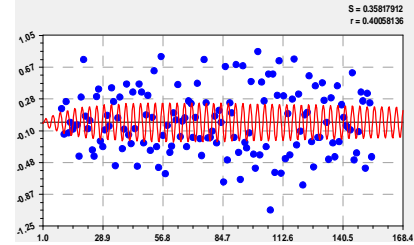

97-ая составляющая

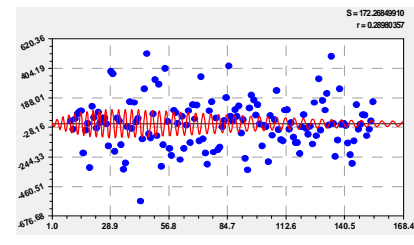

четвертая составляющая

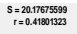

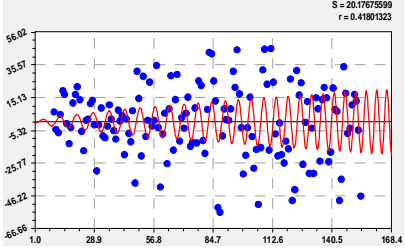

37-ая составляющая

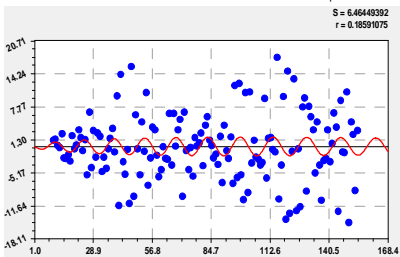

60-ая составляющая

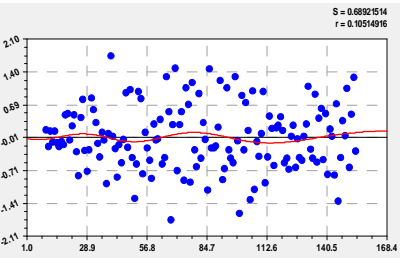

88-ая составляющая

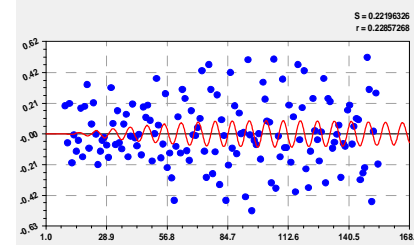

103-ая составляющая

Рис. 4. Графики сквозных составляющих общей динамики суммарной ширины годичного слоя

Затем общий радиальный прирост постоянно снижался. Самым экстремальным для всех 10 дубов был 1869 год, когда общий прирост ниже средней линии тренда более трех раз. По-видимому, аномалия внешнего воздействия этого года сказалось на всем дальнейшем роста и развитии учтенных дубов.

По волновым членам по параметрам (табл. 5) характеристика дана в таблице 6.

Таблица 6. Параметры волны динамики суммарного годичного радиального прироста дубов

\begin{tabular}{|c|c|c|c|l|}
\hline $\begin{array}{c}\text { Номер } \\
i\end{array}$ & $\begin{array}{c}\text { Начальный } \\
\text { полупериод }\end{array}$ & $\begin{array}{c}\text { Начальный } \\
\text { период }\end{array}$ & $\begin{array}{c}\text { Характер } \\
\text { динамики }\end{array}$ & $\begin{array}{c}\text { Параметры активности Солнца, } \\
\text { влияния циклов Земли и Луны }\end{array}$ \\
\hline 2 & 13.85309 & 27,7 & + & $80 \%$ цикла обращения ядра Солнца (22,5 лет) \\
\hline 4 & 1.38379 & 2,8 & + & $1 / 4$ цикла солнечной активности (11.3 лет) \\
\hline 5 & 5.57846 & 11,2 & - & цикл солнечной активности \\
\hline 24 & 2.22612 & 4,5 & - & $40 \%$ цикла солнечной активности \\
\hline 37 & 4.11062 & 8,2 & - & 1,5 полуцикла солнечной активности \\
\hline 42 & 1.31722 & 2,6 & const & $\approx 1 / 4$ цикла солнечной активности \\
\hline 50 & 8.53632 & 17,1 & + & 1,5 цикла активности Солнца (цикл Луны 19 лет) \\
\hline 60 & 6.67836 & 13,4 & + & 1,2 цикла солнечной активности \\
\hline 61 & 4.62403 & 9,2 & const & $80 \%$ цикла солнечной активности \\
\hline 78 & 1.19486 & 2,4 & const & $20 \%$ цикла солнечной активности \\
\hline 88 & 21.93606 & 43,9 & + & двукратный цикл обращения ядра Солнца \\
\hline 89 & 0.81664 & 1,6 & const & $15 \%$ цикла солнечной активности (сезонность) \\
\hline 97 & 1.69893 & 3,4 & const & $30 \%$ цикла солнечной активности \\
\hline 103 & 3.92159 & 7,8 & const & $70 \%$ цикла солнечной активности \\
\hline
\end{tabular}

Примечание. Успокоение (+) или учащение (-) колебания. 
Как видно из данных таблицы 6, на жизнедеятельность дубов основное влияние оказывает всего один цикл активности Солнца (цикл обращения ядра Солнца вокруг своей оси равен двум циклам его активности при смене знаков у полюсов). Части цикла активности Солнца образуются от влияния обращения Земли и Луны [7-9, 13, 14].

\section{ЗАКЛЮЧЕНИЕ}

Дендрохронологические измерения по методу кернов, взятых возрастным буравом на 10 деревьях дуба черешчатого (Quercus robur L.), дали 104 члена общей статистической модели синхронной ежегодной динамики суммарной ширины годичных слоев на высоте 0,5 м от корневой шейки. При этом было выяснено, для повышения точности синхронизации по началу возникновения популяции у деревьев нужно брать керны на уровне корневой шейки. Иначе, из-за сильных различий в условиях произрастания каждой особи дуба, трудно определять нулевой возраст относительно календарной шкалы.

Косвенно был проверен метод перекрестной датировки по абсолютной дате динамики радиального прироста древесины у ствола по ширине годичных слоев. Этот метод дает возможность суммировать радиальные приросты за год у всех учтенных деревьев. Следующий шаг - это проверка относительной датировки, когда календарная дата начала возникновения проростка дуба точно не определена. Для этого придется разделить 10 дубов на три группы по разному началу развития и роста.

Линия тренда подчиняется биотехническому закону, который показывает основную траекторию развития и роста у всех особей популяции. Все остальные 103 члена являются волнами с переменной амплитудой, изменяющейся также по биотехническому закону. Отличие от этого закона показывает какие-то аномалии в поведении популяции. Кроме того, полупериод каждого колебания может иметь возрастающий, постоянный (const) или же убывающий характер. Постоянный полупериод характеризует простую динамику развития и роста деревьев. Как правило, успешно развивающиеся популяции должны иметь успокаивающийся характер, то есть полупериод колебания должен возрастать (частота возмущения - снижаться). Множество вейвлетов с убывающим полупериодом характеризует плохие для жизни деревьев внешние воздействия, влияние которых только учащается и популяция может расстроиться и даже идти в своем развитии «в разнос» (такое явление в двигателе автомобиля приводит к аварии). Аналогично и среди растений: стрессы в виде колебаний с учащением приводят к потере растением способности к саморазвитию.

Анализ полупериода сквозных колебаний, по продолжительности превышающих период с 1850 (начало популяции) по 2004 (измерения на кернах) годов, показал, что основным фактором, влияющим на старт поведения популяции 10 дубов, является цикл солнечной активности, по эффекту А.Л. Чижевского со средней продолжительностью в 11.3 года. Каждый цикл активности Солнца имеет свою продолжительность, кроме этого на циклы поведения популяций растений влияют циклы обращения Земли и Луны. Поэтому образуется спектр из 103 волны общей жизнедеятельности популяции.

\section{СПИСОК ЛИТЕРАТУРЫ}

1. Бюсген М. Строение и жизнь наших лесных деревьев / Пер. с нем. М.-Л.: Гослесбумиздат, 1961. 424 c.

2. Варсегова Л.Ю., Мазуркин П.М., Фадеев А.Н. Практикум по экологическому древоведению / под ред. проф. П.М. Мазуркина. Йошкар-Ола: МарГТУ, 2010. 42 с.

3. Верхунов П.М., Мазуркин П.М. Таксация древесного ствола лесных насаждений: Учеб. пос. Йошкар-Ола: МарГТУ, 1999. 72 с.

4. Колесникова А.А. Исследование свойств древесины по кернам. Йошкар-Ола: МарГТУ, 2002. $178 \mathrm{c}$.

5. Использование кернов древесины в лесоводственных исследованиях: Метод. рекомендации / Д.П. Столяров, О.И. Полубояринов, Н.Н. Декатов и др. Л.: ЛенНИИЛХ, 1988. 43 с. 
6. Ловелиус Н.В. Изменчивость прироста деревьев. Дендроиндикация природных процессов и антропогенных воздействий. Л.: Наука, 1979. 232 с.

7. Мазуркин П.М. Вейвлет-анализ альфа-активности ${ }^{239} \mathrm{Pu}$ во времени солнечного затмения // Наука и мир: международный научный журнал. 2014. № 1(5). С.94-104.

8. Мазуркин П.М. Вейвлет-анализ часовых приращений альфа-активности ${ }^{239} \mathrm{Pu}$ при максимуме солнечного затмения // Наука и мир: международный научный журнал. 2014. № 2(6). Том 1. С.46-55.

9. Мазуркин П.М. Вейвлет-анализ часовых приращений альфа-активности ${ }^{239} \mathrm{Pu}$ после солнечного затмения // Наука и мир: международный научный журнал. 2014. № 3(7). Том 1. С.31-40.

10. Мазуркин П.М. Дендрометрия. Статистическое древоведение: учеб/ пос. Часть 1. ЙошкарОла: МарГТУ, 2003. 308 с.

11. Мазуркин П.М. Дендрохронологические шкалы разновозрастного сосняка // Современные наукоемкие технологии. № 6. 2010. С.32-44.

12. Мазуркин П.М. Дендрохронологические шкалы и возрастная структура разновозрастного сосняка. 12 с. Портал WOOD.RU. URL: http://www.wood.ru/ru/loa732.html.

13. Мазуркин П.М. Динамика альфа-активности ${ }^{239} \mathrm{Pu}$ по этапам солнечного затмения // Наука и мир: международный научный журнал. 2013. № 4(4). С.20-26.

14. Мазуркин П.М. Посуточная динамика альфа-активности ${ }^{239} \mathrm{Pu}$ при солнечном затмении // Наука и мир: международный научный журнал. 2013. № 3(3). С.21-27.

15. Мазуркин П.М. Решение 23-ой проблемы Гильберта // Междисциплинарные исследования в области математического моделирования и информатики. Матер. 3-й научно-прак. internet-конф. Ульяновск: SIMJET, 2014. С 269-277.

16. Мазуркин П.М. Статистическое моделирование многоцикловых процессов // Циклы природы и общества: материалы VI Международной конференции. Часть 1. Ставрополь: Изд-во Ставр. ун-та, 1998. C.213-218.

17. Мазуркин П.М. Энергетика формирования ствола лесного дерева // Лесной вестник. 2000. №1(10). М.: МГУЛ. С.39-43.

18. Мазуркин П.М., Варсегова Л.Ю. Испытание растущего дерева // Успехи современного естествознания. № 4. 2010. С.38-43.

19. Мазуркин П.М., Варсегова Л.Ю. Измерение ширины годичного слоя на керне древесины // Успехи современного естествознания. № 4. 2010. С.31-38.

20. Мазуркин П.М., Варсегова Л.Ю. Измерение ширины годичных слоев сердцевины и присердцевинной зоны растущего дерева с использованием кернов // Деревообр. пром-сть. 2010. № 2. C.25-26.

21. Мазуркин П.М., Варсегова Л.Ю. Ультразвуковое испытание древесины растущего дерева на радиальных кернах // Деревообр. пром-сть. 2010. № 3. С. 29-30.

22. Мазуркин П.М., Демаков Ю.П. Особенности многоволновой динамики радиального прироста сосны // Циклы природы и общества: материалы VI Международной конференции. Часть 2. Ставрополь: Изд-во Ставр. ун-та, 1998. С.174-176.

23. Мазуркин П.М., Долгих М.В. Компонентное равновесие и устойчивость древостоя. ЙошкарОла: МарГТУ, 2011. 164 с.

24. Мазуркин П.М., Колесникова А.А. Изменение энергетики древесины по радиусу ствола // Лесной вестник. 1999. №4(9). М.: МГУЛ. С.115-119.

25. Мазуркин П.М., Петренко А.О. Биоиндикация веточками и иголками ели. Йошкар-Ола: МарГТУ, 2011. 194 с.

26. Мазуркин П.М., Степкина Е.А. Экологическое равновесие древостоя. М.: Изд-во «Академия естествознания», 2009. 240 с.

27. Мазуркин П.М., Филонов А.С. Математическое моделирование. Идентификация однофакторных статистических закономерностей: учебное пособие. Йошкар-Ола: МарГТУ, 2006. 292 с.

28. Мазуркин П.М., Филонова Е.С. Метод анализа дендрометрических данных // Экология: Образование, наука, промышленность и здоровье: материалы II Международной научно-практической конференции. Вестник БГТУ. 2004. №8. Часть V. С.83-85.

29. Тишин Д.В. Дендроэкология (методика древесно-кольцевого анализа): учебно-метод. пос. Казань: Казанский университет, 2011. 33 с.

30. Шипицына Е.Ю., Свидерская И.В., Суховольский В.Г. Формирование структуры годичного кольца хвойных: оптимизационное математическое моделирование // Математическая биология и биоинформатика. 2007. Том 2. №2. С.319-326. 